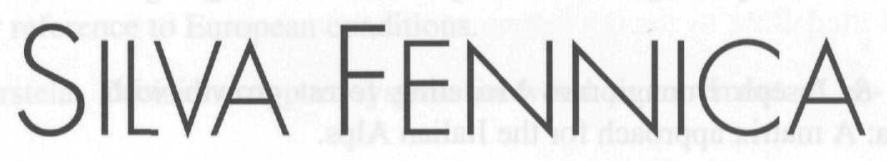

a quarterly journal of forest science

\title{
Contents Vol. 31,1997
}

The Finnish Society of Forest Science

The Finnish Forest Research Institute 
No. 1

\section{Research articles}

Matti Haapanen, Pirkko Velling \& Marja-Leena Annala: Progeny trial estimates of genetic parameters for growth and quality traits in Scots pine.

Pekka E. Kauppi, Maximilian Posch, Pekka Hänninen, Helena M. Henttonen, Antti Ihalainen, Eino Lappalainen, Michael Starr \& Pekka Tamminen: Carbon reservoirs in peatlands and forests in the boreal regions of Finland.

Paola Virgilietti \& Joseph Buongiorno: Modeling forest growth with management data: A matrix approach for the Italian Alps.

Harri Mäkinen: Possibilities of competition indices to describe competitive differences between Scots pine families.

Matti Maltamo: Comparing basal area diameter distributions estimated by tree species and for the entire growing stock in a mixed stand.

Timo Tokola \& Juho Heikkilä: Improving satellite image based forest inventory by using a priori site quality information.

\section{Review articles}

Arja Lilja, Sakari Lilja, Timo Kurkela \& Risto Rikala: Nursery practices and management of fungal diseases in forest nurseries in Finland. A review.

Gregory S. Amacher: The design of forest taxation: A synthesis with new $101-119$ directions.

\section{Reviewers of manuscripts 1996}

Instructions to authors

\section{No. 2}

\section{Research articles}

Mikko Peltonen, Kari Heliövaara \& Rauno Väisänen: Forest insects and environmental variation in stand edges.

Mika Jääskelä, Mikko Peltonen, Hannu Saarenmaa \& Kari Heliövaara: Comparison of protection methods of pine stacks against Tomicus piniperda.

Andrew P. Robinson, Timothy G. Gregoire \& Harry T. Valentine: Cut-off importance sampling of bole volume.

Hannu Hökkä, Virpi Alenius \& Timo Penttilä: Individual-tree basal area 
growth models for Scots pine, pubescent birch and Norway spruce on drained peatlands in Finland.

Teijo Palander: A local DLP-GIS-LP system for geographically decentralized wood procurement planning and decision making.

\section{Review articles}

Marja-Leena Nykänen, Heli Peltola, Christopher Quine, Seppo Kellomäki \& Marianne Broadgate: Factors affecting snow damage of trees with particular reference to European conditions.

Pertti Harstela: Decision support systems in wood procurement. A review.

\section{Research note}

Anne Toppinen: Testing for Granger-causality in the Finnish roundwood market.

\section{Book review}

Peter Koch, 'Lodgepole Pine in North America', reviewed by Pentti Hakkila.

\section{No. 3 Special issue on Functional-Structural Tree Models}

\section{Research articles}

Christine Deleuze \& François Houllier: A transport model for tree ring width.

Harry T. Valentine: Height growth, site index, and carbon metabolism.

Hervé Sinoquet, Pierre Rivet \& Christophe Godin: Assessment of the three-dimensional architecture of walnut trees using digitising.

Thomas Früh: Simulation of water flow in the branched tree architecture.

Winfried Kurth \& Branislav Sloboda: Growth grammars simulating trees - an extension of L-systems incorporating local variables and sensitivity.

Philippe de Reffye, Thierry Fourcaud, Frédéric Blaise, Daniel Barthélémy \& François Houllier: A functional model of tree growth and tree architecture.

Séverine Le Dizès, Pierre Cruiziat, André Lacointe, Hervé Sinoquet,

Xavier Le Roux, Philippe Balandier \& Patrick Jacquet: A model for simulating structure-function relationships in walnut tree growth processes.

Risto Sievänen, Eero Nikinmaa \& Jari Perttunen: Evaluation of importance of sapwood senescence on tree growth using the model LIGNUM. 


\section{Review articles}

John H. M. Thornley: Modelling allocation with transport/conversion proc$341-355$ esses.

Christophe Godin, Evelyne Costes \& Yves Caraglio: Exploring plant $357-368$ topological structure with the AMAPmod software: an outline.

\section{Research note}

Annikki Mäkelä, Petteri Vanninen \& Veli-Pekka Ikonen: An application $369-380$ of process-based modelling to the development of branchiness in Scots pine

\section{No. 4}

\section{Research articles}

Seppo Kaunisto \& Tytti Sarjala: Critical needle potassium concentrations indicated by diamine putrescine in Norway spruce growing on peat soils.

Leena Finér \& Mika Nieminen: Dry mass and the amounts of nutrients in $391-400$ understorey vegetation before and after fertilization on a drained pine bog.

Tommi Ruha \& Martti Varmola: Precommercial thinning in naturally regenerated Scots pine stands in northern Finland.

Timo Pukkala, Jyrki Kangas, Matleena Kniivilä \& Anne-Mari Tiainen: Integrating forest-level and compartment-level indices of species diversity with numerical forest planning.

Janne Uuttera \& Harri Hyppänen: Relationship between forest management planning units and spatial distribution of forest habitat components in Koli National Park.

\section{Review article}

Markku Tykkyläinen, Pentti Hyttinen \& Ari Mononen: Theories on regional development and their relevance to the forest sector.

\section{Research note}

Dimitris Athanassiadis: Residual stand damage following cut-to-length harvesting operations with a farm tractor in two conifer stands. 


Submission Manuscripts should be submitted in triplicate to Silva Fennica, Unioninkatu 40 A, FIN-00170

of Manuscripts Helsinki, Finland. Manuscripts may also be submitted in PDF format via e-mail to silva.fennica@metla.fi. Detailed instructions to authors are printed in the first issue each year, are available from the editorial office, and can be found on Silva Fennica's WWW pages at http://www.metla.fi/publish/silva/

Publication Silva Fennica is issued in four numbers per volume.

Schedule

Subscriptions Subscriptions and orders for back issues should be addressed to Academic Bookstore, Suband Exchange scription Services, P.O. Box 108, FIN-00101 Helsinki, Finland, Phone +358 9121 4322, Fax +358 9121 4435. Subscription price for 1997 is 300 FIM. The price for subscriptions from Finland is 200 FIM, and these are best addressed to the Finnish Society of Forest Science. Exchange inquiries should be addressed to the Finnish Society of Forest Science, Unioninkatu 40 A, FIN-00170 Helsinki, Finland, Phone +358 98570 5235, Fax +358 98570 5677, E-mail sms@helsinki.fi

Statement Silva Fennica has been published since 1926 by The Finnish Society of Forest Science. From of Publishers 1994, the journal is published by the Finnish Society of Forest Science and the Finnish Forest Research Institute. The Finnish Society of Forest Science is a nonprofit organization founded in 1909 to promote forest research. Its publishing functions are supported by the Academy of Finland. The Finnish Forest Research Institute, founded in 1917, is a research organization financed by the Ministry of Agriculture and Forestry.

Abstracting Articles in Silva Fennica are abstracted and indexed in Agrindex, Biological Abstracts, Current Advances in Ecological Sciences, Current Advances in Plant Sciences, Ecological Abstracts, Forest Products Journal, Forestry Abstracts, International Bibliography of Periodical Literature, Life Sciences Collection. 


\section{The Finnish Society of Forest Science The Finnish Forest Research Institute}

\section{Research articles}

Seppo Kaunisto \& Tytti Sarjala: Critical needle potassium concentrations indicated by diamine putrescine in Norway spruce growing on peat soils.

Leena Finér \& Mika Nieminen: Dry mass and the amounts of nutrients in understorey vegetation before and after fertilization on a drained pine bog.

Tommi Ruha \& Martti Varmola: Precommercial thinning in naturally regenerated Scots pine stands in northern Finland.

Timo Pukkala, Jyrki Kangas, Matleena Kniivilä \& Anne-Mari Tiainen:

Integrating forest-level and compartment-level indices of species diversity with numerical forest planning.

Janne Uuttera \& Harri Hyppänen: Relationship between forest management planning units and spatial distribution of forest habitat components in Koli National Park.

\section{Review article}

Markku Tykkyläinen, Pentti Hyttinen \& Ari Mononen: Theories on regional development and their relevance to the forest sector.

\section{Research note}

Dimitris Athanassiadis: Residual stand damage following cut-to-length 